\title{
A Preliminary Study of Kaoka 高甲 Playscripts in the Philippines
}

\author{
Caroline Chia
}

\section{Introduction}

As part of a book on Sinitic languages in Southeast Asia, particularly those that are increasingly endangered, this chapter emphasizes "Sinophone" and "Sinitic voices" in the Philippines. Briefly defined, the Sinophone landscape involves Sinitic languages, including Hokkien, and the associated cultures and communities which historically experienced colonialism and have increasingly been marginalized in more recent times. ${ }^{1}$ Here I focus on Sinophone speech, including the soundscapes in which speech is embedded, through theatrical performance in Hokkien. Kaoka was once a popular form of entertainment in Southeast Asia, but the Philippines is the only country in the region that still performs this theatrical art today. I furthermore aim to highlight the diversity of Sinophonic representations as seen in Kaoka playscripts. In these sources, only the phonetic elements have been preserved, whereas the logographic representations (known as Sinographs or Hanzi 漢字) have been omitted. As regards the "Sinitic voices" that this chapter - and this book in general aims to highlight in the context of Southeast Asia's Chinese minorities, the academic focus has previously been on the migration and economic development of Chinese communities in this region. These developments remain important and will be taken into consideration, but the focus here is on filling the cultural and linguistic gaps in scholarship on Kaoka in the Philippines.

The people from south Fujian, known as the Hokkiens (ban lam lang 閩南 人), came in large numbers and migrated to different parts of Southeast Asia. ${ }^{2}$ Despite Southeast Asia's relatively early interactions with Chinese people

1 Part of this definition is adapted from the Cambria Sinophone World Series, http://www .cambriapress.com/cambriaseries.cfm?template $=85$, retrieved 25 April 2020.

2 In this chapter, I use Hokkien interchangeably with Southern Min (ban-lam in the Hokkien vernacular, referring to south Fujian) unless otherwise stated, as the former continues to be a term commonly used to refer to people and the language from south Fujian. However, Dory Poa, a Filipino Chinese, has alerted me that the Filipino Chinese community, particularly those whose ancestral origin was from south Fujian, often refer to their language as ban 
from this region, with migration occurring as early as the sixteenth and seventeenth centuries, south Fujian is understudied particularly in its sociocultural development. Given their historical importance in Southeast Asia, it is useful to study how the language and culture of the Hokkien migrants - though originating from southern Fujian - was later subjected to the sociocultural and political contexts of the areas they migrated to, which resulted in some distinct differences across Southeast Asia.

Despite their long-time involvement and significance in Southeast Asia, studies on the language and culture of the Hokkien community in the Philippines remain limited. This chapter draws on various disciplines - including linguistics, sociology, anthropology, and religious studies - to achieve a more well-rounded understanding of the topic, especially when sources are scant. Henning Klöter's (2011) work on Early Manila Hokkien (EMH) is noteworthy, as he engaged in a pioneering study of this significant but otherwise largely ignored area. The study of EMH attests to the important role played by the Hokkien community as early as the seventeenth century. A comparative study of the Kaoka texts and EMH, as will be attempted here, can reveal some trends and changes in the development of the Hokkien vernacular in the Philippines. It furthermore underscores some local specificities of Sinophone culture, ${ }^{3}$ by investigating how the Hokkien spoken in the Philippines differs from that of other parts of Southeast Asia and Fujian. In the 1980s, Gloria Chan Yap conducted a comprehensive study on Hokkien loanwords in Tagalog (Yap 1980). A more recent study by Wilkinson Daniel Wong Gonzales on Philippine Hybrid Hokkien ( $\mathrm{PHH}$ ) substantiates the continued importance and relevance of Hokkien among the Chinese population in the Philippines (Gonzales 2018). Yet despite these illuminating studies, there are some distinct differences between spoken Philippine Hokkien and language of the Kaoka texts. The latter forms this chapter's main focus of analysis.

Kaoka in the Philippines has existed for a century, but scholarly discussions on this theatrical form remain scant. Noting the popularity of various theatrical forms brought along by successive waves of migration from China to Southeast Asia, Chinese scholars occasionally mention Kaoka in the Philippines, but information remains scattered. ${ }^{4}$ Despite their lack of a coherent analysis, these studies remain important as they provide a basic understanding of the way

lam ue 閩南話 and their people as ban lam lang 閩南人 rather than Hokkien. With this in mind, the term Hokkien is used with caution.

3 According to Shih's pioneering study of the Sinophone (2013: 7), "Sinophone culture is placebased and belongs to the place where it is produced".

4 Cf. Zhuang (2006), Bai (2011: 64-68), and Wu (2006). 
Kaoka developed - especially before the Second World War (1942-45) - which is lacking in English scholarship. Sources about Kaoka written by Filipino Chinese, also known as Tsinoys, are equally noteworthy, as they represent their efforts and interest to document a traditional theatrical form from their home country. Anson $\mathrm{Yu}$, for example, is a heritage enthusiast and has written a number of articles on Kaoka. Two of his articles were published in Tulay, a fortnightly Filipino Chinese newspaper still in print today (Yu 2007, 2013). There is also a study by Percy G. Ng on the socio-historical context of the genre. This author's interviews of present-day Kaoka performers have been particularly useful for my own research (Ng 2016). Josh Stenberg's recent publication on Chinese opera (戲曲 xiqu) in the Philippines further illustrates the relatively early existence of various forms of traditional Chinese theatre in this country, compared to the rest of the Southeast Asian region (Stenberg 2020: $5^{8-89}$ ).

This chapter combines two main research objectives. First, it provides a succinct timeline indicating when Kaoka was transmitted to the Philippines from its period of transmission up to the present day - as previous literature outlining this development is absent. Second, it conducts a preliminary analysis on the Kaoka playscripts, which can contribute to an understanding of the sociolinguistics of the Filipino Hokkien community, including the documentation of this theatrical form once popular across Southeast Asia but today only known in the Philippines.

\section{Kaoka in the Philippines: Past and Present}

Chinese migration and settlement in the Philippines was relatively early compared to counterparts elsewhere in Southeast Asia. There is evidence indicating Chinese presence prior to the arrival of the Spanish in the sixteenth century. ${ }^{5}$ However, it is questionable to assume that Kaoka appeared in this period. ${ }^{6}$ My conviction, that Kaoka appeared in the Philippines during the early twentieth

5 In his study of the language of Early Manila Hokkien (EMH), Klöter (2011: 172-73) holds that the time period of early Chinese (known as Sangley) settlement was in the late fifteenth century.

6 Using a rich variety of Chinese, English, and Spanish sources, Stenberg (2020) has outlined the history of Chinese opera (xiqu) in the Philippines from the sixteenth century. However, as emphasized in the present chapter, it is unlikely that Kaoka appeared in the Philippines before the twentieth century. As my discussion is focused on Kaoka, other theatrical forms are beyond its scope. 
century, is supported by a number of observations. ${ }^{7}$ Kaoka - pronounced as $k a u$-kah in the Southern Min (閩南 Minnan) or Hokkien language, ${ }^{8}$ and more commonly known in contemporary China as Gaojia opera 高甲戲 - only matured into a theatrical genre in south Fujian during the nineteenth century. Due to the high demand of the Chinese communities abroad, Kaoka opera troupes from south Fujian regularly travelled to perform in Southeast Asia, particularly from the 1840 os to the 1930s. Chinese sources indicate that the earliest existence of Kaoka in the Philippines can be traced to the 1920s, particularly through the establishment of local troupes known as 'Luzon troupes' (呂宋班 Lüsong ban). So far, no source provides an explanation why these troupes were so named, but Luzon was undoubtedly a site of significance among the Chinese community in the Philippines. ${ }^{9}$

7 This is also supported in a paper of somewhat ambiguous authorship (Fei hua 2007: 802, 8o9), which shows that when America defeated Spain towards the end of the nineteenth century and took over the latter's control of the Philippines, their more relaxed rule led to the influx and flourishing of Chinese migrants and their hometown culture, including Kaoka. Some sources state that this paper was authored by $\mathrm{Li} \mathrm{Li}$ 李麗, but the actual reference does not specify the author's name. Hence, I will refer to this source as "Fei hua 2007 " in this chapter.

8 The term Kaoka is used throughout this chapter instead of Gaojia 高甲 opera, as the latter did not appear until 1949. Kaoka is the term used by the performers whom I have interviewed in the Philippines. It is etymologically interlinked with other Hokkien words, including káu-kah 九甲～九角 'nine character-roles', believed to derive from the 'seven-child' or 'seven-actor' roles in its predecessor, Liyuan opera 梨園戲. Two types of painted faces were later added to form the nine character-roles. These are the male (sheng 生), female (dan 旦), painted face (jing 淨), bearded male (mo 末), elderly female (tie 貼), supporting role playing miscellaneous roles (wai 外), and villain (shumei 豎眉). Another similar term is 'armour and dagger' (gejia 戈甲) to denote the military costumes and weapons used in Kaoka on stage, the highlight of which is often martial plays (wuxi 武戲). The word furthermore resembles the term 'standing on the high stage and wearing armour' (登高臺穿盔甲 deng gaotai chuan kuijia or 高甲 gaojia in short), denoting the military plays performed in Kaoka. Finally, when Kaoka spread to Southeast Asia during the nineteenth century, it won great acclaim and was regarded as 'high quality and A-grade' (高等甲等 gaodeng jiadeng or 高甲 gaojia in short) by the local Chinese community (Zhuang 2008: 136, "Fujian sheng" 2000: 33). All these folk etymologies contribute to the specific meanings the word Kaoka has acquired over time.

9 According to Hung (2014), when the Spanish colonized the Philippines in 1571 and before Koxinga 國姓爺 (Zheng Chenggong) occupied Taiwan - allowing the large influx of migrants from south Fujian - Luzon, the main island of the Philippines, appeared to be the only destination for migrants from China. Possibly also due to its proximity, most of the migrants who travelled to Luzon during this period and eventually settled there were from Zhangzhou (south Fujian). 
Two associations for traditional southern Fujianese music (南音 Nanyin), ${ }^{10}$ notable for their role in popularizing Kaoka to the migrant and local Chinese populations in the Philippines, were the Philippine Sy Tiok Music Association (絲竹尚義社 Sizhu shangyishe) established in 1922 and the Philippine Song Lim Musical Association (桑林陽春總社 Sanglin yangchun zongshe) established in $1923 .{ }^{11}$ As will be discussed later, Nanyin is closely linked to Kaoka and the theatrical form is sometimes referred to as 'the (excellent) theatre of Nanyin' (南音佳劇 Nanyin jiaju). ${ }^{12}$ It was also during the 1920s, arguably the peak of Kaoka in Southeast Asia, that representatives of these associations from the Philippines travelled to China and invited performers to the theatres in Manila, situated mainly at Ongpin Street (王涁街 Wangbin jie) and possibly Alonzo Street (阿籠計街 Ahlongji jie). Given its popularity with the Chinese, these performers were employed for a duration ranging from a few months to a year or two (Bai 2011: 64; Fei hua 2007). The Luzon troupes also mark the period when Kaoka thrived in the Philippines. Their activities came in five phases: the first Luzon troupe from 1919 to 1921, the second in 1921, the third from 1922 to 1923 , the fourth from 1934 to 1936 , and the fifth from 1936 to $1937 . .^{13}$ The first Luzon troupe, also one of the most notable, was organized by Li Zaiju 李仔居 of the Song Lim Musical Association, who returned to south Fujian and invited the performers there to travel to the Philippines and perform at the Xintang theatre 新堂戲院 on Ongpin Street. Over the course of more than a year, more than 400 shows were staged, indicating its popularity among the Chinese in the Philippines (Bai 2011: 65).

From the 1920s to 1930s, the repertoire staged by the Kaoka performers typical of traditional theatre in south Fujian, including Flood at Jinshan Temple

10 Nanguan or Nanyin emerged during the Tang Dynasty. It was believed that during the reign of Emperor Xizong 唐僖宗 in $885 \mathrm{CE}$, the brothers Wang Chao 王潮 and Wang Shenzhi 王審知 led their army to the Min area, bringing over "big tunes" (大曲 daqu). Nanyin preserves some musical influences of the Central Plain, while assimilating local Min music (Chen \& Xu 2009: 521).

11 These dates were obtained from Zhuang (2012: 764$)$.

12 Scholars have different views on whether "Nanyin" theatre refers to Liyuan opera or Kaoka. There is also a third view, that Nanyin or Nanguan 南管 theatre refers to both theatrical forms (Shih 2012: 10).

13 The active years of the Luzon troupes slightly differ in Li's source, namely 1921-23, 1921-22, and 1923-24. Due to the lack of other sources, we can only deduce that the Luzon troupes were active around the 1920s and possibly before the outbreak of the Second World War (Fei hua 2007; Bai 2011: 65-66). Note also that Nanyin in the Philippines existed during the nineteenth century, so the Luzon troupes would have existed before the establishment of some of the Nanyin associations. Further detail is beyond the scope of this chapter and will require more research. 
(水淹金山寺 Shuiyan Jinshansi), Ziya Slays Three Demons (子牙捉三妖 Ziya zhuo sanyao), Datong City (大同城 Datong cheng), Disguising as Elderly Couple (公婆拖 Gongpo tuo), The Jade Lovebirds Fan (玉骨鴶驀扇 Yugu yuanyang shan), Rousing the Bridal Chamber (銿洞房 Nao dongfang), The Foreign Woman Causing a Commotion (番婆弄 Fanpo nong), Tang Er Leaves his Wife (唐二別妻 Tang Er bieqi), Beating the Wife (姈婆打 Lingpo da), The Frantic Monk Scolds Qin Kuai (瘋僧罵秦檜 Feng seng ma Qin Kuai), and Guan Fu Leaves his lover (管甫送 Guan Fu song). ${ }^{14}$ A number of these shows were popular stories emphasizing the clown (\# . chou) role, which was a common feature of Kaoka. ${ }^{15}$

The performance of Kaoka came to an abrupt halt with the outbreak of the Second World War and the Japanese occupation of the Philippines. Kaoka performances that catered for traditional celebrations, such as weddings, birthdays for elders, and religious festivities, resumed after the war (Bai 2011: 65 ). While it would appear that the cultural and entertainment scene was similar to the pre-War situation, the socio-political climate - most notably after the Philippines' declaration of independence in 1946 and the outbreak of the Cold War in 1947 - had a drastic impact on international and familial relations. This in turn affected Kaoka. Taiwan, instead of mainland China, soon became a close ally of the Philippines, especially because of geopolitical and ideological concerns. The post-War era also saw the increasing reliance of both the Republic of China (вос) in Taiwan and of the Philippines on the United States. ${ }^{16}$ Their alliance was further heightened by the containment strategy adopted by the United States during the Cold War. Sharing a common ancestral origin with the Taiwanese, the Chinese in the Philippines, particularly those of south Fujian origins, also began to demonstrate closer cultural affiliations with the former.

As mentioned earlier, the Nanyin associations played a significant role in bringing Kaoka performances in the Philippines to their peak during the 1920 . Although the political climate of the post-War period went through a dramatic transition, the role of Nanyin and its theatrical forms continued to be - to quote

\footnotetext{
14 This repertoire is given in Bai (2011: 65-66).

15 As Gaojia opera began to mature as an opera form complete with makeup, music, singing, stage movements, and storyline, it also developed the distinctive trait of featuring the clown character, to the extent that this character role became synonymous with the operatic form. The significance of the clown role in Gaojia opera is mentioned in Bai (2011: 66-67).

16 The policy of "getting close to Taiwan and away from mainland China" (親台灣遠 大陸 qin Taiwan yuan Dalu) as well as the strong influence of the United States on the Philippines is mentioned in Fei hua (2007: 825) and Wickberg (2006: 22).
} 
Tan and Rao in their definition of Sino-soundscapes - "intentionally produced and created in ways to register distinctive identity and articulate cultural positions in particular places" (Tan \& Rao 2016: 6). This form of cultural exchange between Taiwan and the Philippines was evident.

During the Cold War era, Taiwanese troupes allowed to travel overseas were often backed by a political agenda, exemplified by the slogan "repel the Communists and resist the Soviets" (反共抗俄fan gong kang e). In 1958, the Hsin Li-yuan troupe 新麗園劇團 - formed by the Pao-tao (寶島; lit. “Treasure island, a popular reference for Taiwan) Gezai opera troupe and the exclusive Gaojia opera troupe for the military (軍中專屬高甲戲團 junzhong zhuanshu Gaojiaxi tuan), led by the Airforce leader Lin Chin-chih 林金池 - visited the Philippines in the name of establishing a rapport with the local Chinese. The visit lasted for about three months (Fei hua 2007: 828). Later, in August 1958, the I-chun Yuan troupe 宜春園, established by the I-chun Yuan Gezai opera troupe and Hsin chin-chu 新錦珠 Gaojia opera of Taichung, was invited by a Filipino Chinese man named Gao Qingyun 高慶雲. It should be noted that a number of Taiwanese troupes that visited the Philippines were joint Gezai-Gaojia ensembles. The name of the troupe usually followed that of the Gezai opera troupe, which suggests that Gezai opera was the key player in these performances, whereas Gaojia opera performances only played a supporting (客串 kechuan) role. This is not surprising in view of the general trend of Gezai dominance over the older Gaojia opera in Taiwan as well as other parts of the Southeast Asia, such as Malaya and Singapore. However, this was not the case in the Philippines. According to the recollection of Gaojia opera performer Chen Hsiu-Feng 陳秀鳳, “[ $t$ ]o the surprise of the troupe, the supporting role played by Gaojia opera stole the limelight from Gezai opera. As a result, Gaojia opera performances were continuously added and when the troupe released their program, the tickets were sold out three days before the performance" (Fei hua 2007: 828). The prevalence of Kaoka, despite its dwindling role in other parts of Southeast Asia and Taiwan where the Hokkien communities were most populous, continued to enjoy strong support from the Chinese community in the Philippines. I would argue that this persistence was closely associated with the unifying vigour of the Nanyin tradition, yielding a significant Sino-soundscape rooted in the nineteenth century. ${ }^{17}$

17 For example, two Nanyin associations, namely Changhe Langjun she 長和郎君社 and Jin Lan Langjun she 金蘭郎君社 were said to be established during the early nineteenth century (Fei hua 2007: 807). 
Socio-political developments after the Second World War did not dampen the enthusiasm of the Filipino Chinese for Kaoka. The Philippines became one of the major centres in Southeast Asia to organize Kaoka-related activities. Another factor that prompted local developments and establishments of Kaoka troupes was the inability of many performers and musicians to return to their hometown due to the civil war between the Nationalists and the Communists and the resulting political instability in mainland China. Since there was a strong support for Kaoka, they decided to settle or temporarily remain in the Philippines (Fei hua 2007: 842). In 1950, the Shengxing troupe 勝興劇團 was established. According to Teresita Bee Hua Chan 曾美華 (hereafter referred to as Teresita Chan), her teachers Wu Yumu 吳于目 and Wang Shanda 王善達, who were natives from Amoy, decided to remain in the Philippines when the war broke out and eventually established their troupe when the war was over. In 1951, Nanguo Drama Society 南國劇㙯社 was founded. The Xiu Lian Xing troupe 秀聯興劇團 was established in 1962,18 and the Kim Siu Eng troupe 金秀英劇團 in 1965 by Kim Siu Eng, a renowned performer and foster mother of Teresita Chan. ${ }^{19}$ Particularly in the case of the Nanguo Drama Society and the Shengxing troupe, which made efforts to transmit the theatrical form, children were recruited as apprentices of Kaoka and supervised by experienced teachers. These local troupes often performed in traditional contexts, particularly those related to deities' feast days and celebrations organized by various associations. For example, on 20 June 1957, the Song Lim Musical Association invited the Shengxing troupe to perform in celebration of the feast day of Master Guan (Guan Fuzi 關夫子) and on 10 April 1963, the Dadao Shrine 大道 玄壇 invited the Xiu Lian Xing troupe to perform on the feast day of their Grand Master Yun Meng 雲夢祖師 (Fei hua 2007: 842-43). These local establishments were able to continue the legacy in collaboration with their predecessors from Fujian, but their success was met with various challenges ahead.

The 1970s was a watershed for Kaoka in the Philippines, which saw a change in the enthusiasm and support for this form of traditional theatre. Locally established troupes performed in the traditional context, that is, an outdoor stage erected near or within the temple compound. ${ }^{20}$ As mentioned

\footnotetext{
18 Pan (2013: 222), cited in Stenberg (2020: 77).

19 Fei hua (2007: 842). Personal interview, Teresita Bee Hua Chan, 6 October 2017. For troupes where the actual spelling is not known, the hanyu pinyin version is used instead.

20 Unlike their predecessors, locally established troupes were said to perform in temple contexts and less so in indoor theatres (Fei hua 2007: 842). As recalled by Hau (2020) cited in Stenberg (2020: 72), makeshift stages performing Kaoka used to be erected on the streets.
} 


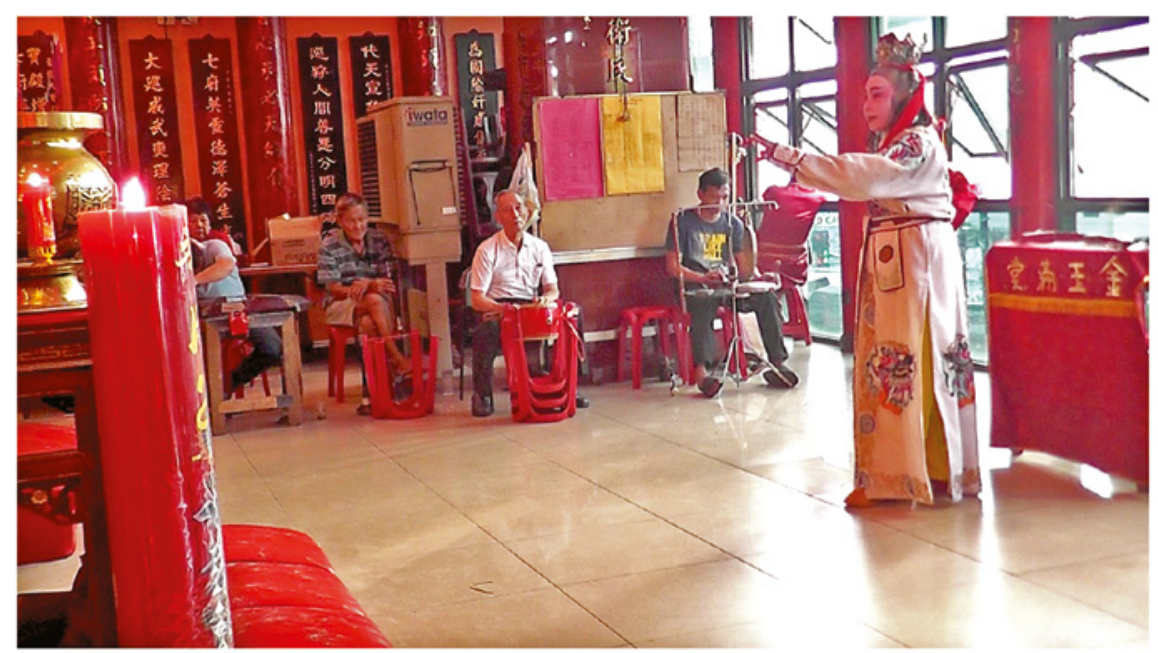

FIGURE 6.1 Kaoka performance inside Qing Long Dian without any stage setup OWN WORK

earlier, local troupes performed on the feast days of deities during the 1950s and 196os. These outdoor performances came to a halt when then President Ferdinand E. Marcos issued Proclamation No. 1081 on 21 September 1972, declaring martial law in the Philippines. ${ }^{21}$ The martial law period (1972-81) meant that curfews were enforced throughout the country that lasted from 12 midnight to 4 in the morning. Those found loitering on the streets at these hours were detained. The curfew affected Kaoka performances, which could previously go on for hours till near midnight. For fear of being detained or questioned, the patrons of Kaoka diminished. With a sharp drop in audiences and supporters, temple invitations of Kaoka troupes were drastically affected too. For example, a seven-day performance was reduced to three days, which

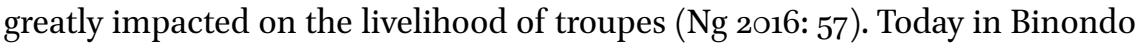
(known as Manila's Chinatown), Kaoka performances are staged inside the temple premises without any stage setup (Fig. 6.1).

The Hoc Kian troupe led by Teresita Chan has been selected for this chapter, particularly because the troupe leader was associated with older local establishments. These include the founders of the Shengxing troupe, who were her teachers, and Kim Siu Eng of the Kim Siu Eng troupe, who was a personal teacher and foster mother of Teresita Chan. During my fieldwork conducted in Manila and Bulacan in 2017, the Hoc Kian troupe appeared to be quite active

21 Ng (2016: 56); Official Gazette, Declaration of Martial Law, retrieved 4 December 2019: https://www.officialgazette.gov.ph/featured/declaration-of-martial-law/. 
and within a week, I observed two performances respectively at Si Wang Fu (鎮池宮古坑四王府 Zhenchigong gukeng siwangfu) on 1 and 2 December, and Qing Long Dian 青龍殿 on 3 and 4 December.

From my observation on the Hoc Kian troupe led by Teresita Chan, it appears that she conforms to the traditional context as much as possible in terms of the music, repertoire, and performance. All these aspects contribute to the sustenance of the Sino-soundscape as expected by the larger traditional Filipino Chinese community. This sustained Sinophone heritage is also evident in the textual representation of Kaoka. Teresita Chan revealed that her proficiency in Chinese, whether spoken or written, was low, as she did not pay a lot of attention to learning the language during her school days. However, the knowledge or craft literacy required for Kaoka meant that she had to learn various aspects of the Sinophone: knowing the Chinese characters (Sinographs) of the repertoire and creating romanizations of the Hokkien vernacular, in this case the Kaoka playscripts, so that performers could learn them. ${ }^{22}$

The repertoire, as presented in Table 6.1, is an outline of various story titles (Fig. 6.2) written by Teresita Chan by hand, including in a non-standard orthography shown in the leftmost column. For story titles that contain non-standard orthographic characters, I have included the corresponding standardized characters to provide the reader with a better sense of the story or main character in relation to the traditional Hokkien theatre or other Chinese opera forms. For example, Wang Lihua Descends from the Mountains (王麗華下山 Wang Lihua xia shan) actually refers to Fan Lihua Descends from the Mountains (樊梨花 下山 Fan Lihua xia shan), which will be analysed later. Teresita explained that it is required of her as the troupe leader to write this repertoire (Fig. 6.2), as the temple personnel will usually seek permission of the deity through the tossing of divination blocks (Hokkien: puah-pue 跋桮; Mandarin: zhijiao 橂䇣) to determine which story title is to be performed. This traditional way of selecting the story title from a repertoire is also observed in the Hokkien theatre of Quanzhou. ${ }^{23}$

22 Craft literacy is regarded as special knowledge usually limited to a specialized group engaged in the same craft. For a more in-depth discussion on this, see Goody (1975).

23 As Ruizendaal (2006: 152) observes in his study of the marionette theatre in Quanzhou, "the names of the plays were written on a traditional harmonica-like list ... the list was opened at the name of one play and placed on the altar and by the throw of the divination blocks the deity would decide which play(s) was to be performed". 


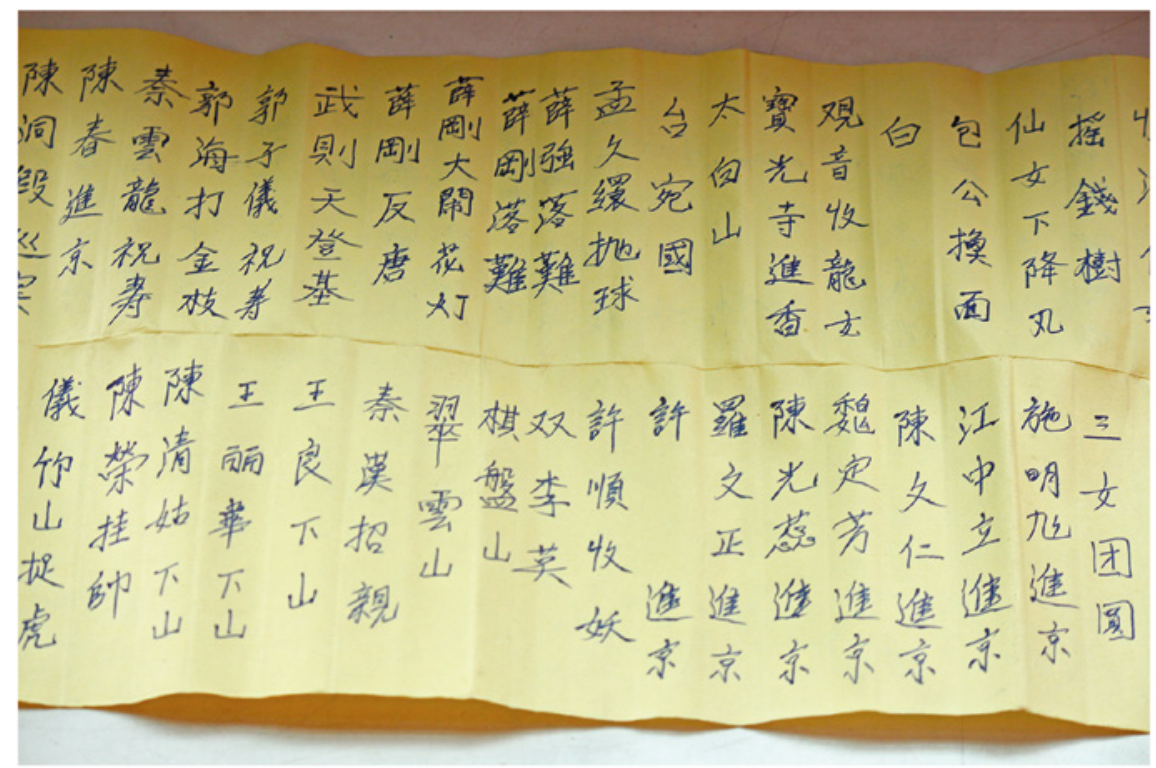

FIGURE 6.2 An image of part of the repertoire written by Teresita Chan OWN WORK

TABLE 6.1 Repertoire of the Hoc Kian troupe

Repertoire Default title English translation
as written by
Teresita Chan

\section{八仙過海}

王母祝壽

李洞涁收妖

四仙記

收河仙姑

搖錢樹

仙女下降凡

包公換面

觀音收龍女

寶光寺進香
Eight immortals cross the sea

Wishes on Queen Mother's birthday

Lü Dongbin subdues the demon

Story of the Four Immortals

Subduing He Xiangu

The coin-shedding tree

The fairy descending to the mortal world

The real and fake Justice $\mathrm{Bao}^{\mathrm{a}}$

Guanyin accepts Dragon Girl as disciple

Offering incense at Baoguang temple

a My speculation is that this is related to the story The Real and Fake Justice Bao 真假包公. However, this will require further verification based on the details of this story. 
TABLE 6.1 Repertoire of the Hoc Kian troupe (cont.)

Repertoire $\quad$ Default title English translation
as written by
Teresita Chan

\begin{tabular}{|c|c|c|}
\hline \multirow{2}{*}{\multicolumn{2}{|c|}{$\begin{array}{l}\text { 太白山 } \\
\text { 台宛國 }\end{array}$}} & Mount Taibai \\
\hline & & Kingdom of Tai Wan \\
\hline 孟久缳抛球 & 孟九環抛球 & Meng Jiuhuan tosses the bouquet ${ }^{b}$ \\
\hline 薛強落難 & & The misfortune of Xue Qiang \\
\hline 薛剛落難 & & The misfortune of Xue Gang \\
\hline 薛剛反唐 & & Xue Gang goes against Tang kingdom \\
\hline 武則天登基 & & Wu Zetian ascends the throne \\
\hline 郭子儀祝壽 & & Guo Ziyi offers his birthday wishes \\
\hline 郭海打金枝 & & Guo Hai beats Jin Zhi \\
\hline 秦雲龍祝壽 & 秦雲龍祝壽 & Qin Yunlong offers his birthday wishes \\
\hline 陳春進京 & & Chen Chun travels to the capital \\
\hline 陳洞假巡案 & & The Fake Investigation by Chen Dong \\
\hline 李淵登基 & & Li Yuan ascends the throne \\
\hline 王寶釧抛球 & & Wang Baochuan tosses the bouquet \\
\hline 湘江會 & & The meeting at Xiang River \\
\hline 麒麟山 & & Mount Qilin \\
\hline 楊宗保取木棍 & & Yang Zongbao retrieves the wooden stick \\
\hline 穆桂英招親 & & Mu Guiying invites the groom \\
\hline 征南戟國 & 征南戰國 & Heading south for war \\
\hline 三女團圓 & & Reunion of the three maidens \\
\hline 施明九進京 & 施明旭進京 & Shi Mingxu travels to the capital \\
\hline 江中立進京 & & Jiang Zhongli travels to the capital \\
\hline 陳久仁進京 ${ }^{\mathrm{c}}$ & & Chen Jiuren travels to the capital \\
\hline 魏定芳進京 & & Wei Dingfang travels to the capital \\
\hline 陳光荵進京 & & Chen Guangrui travels to the capital \\
\hline 羅文正進京 & & Luo Wenzheng travels to the capital \\
\hline 許？進京d & & $\mathrm{Xu}$ travels to the capital \\
\hline 許順收妖 & & Xu Shun subdues the demon \\
\hline
\end{tabular}

\footnotetext{
b This story is associated with Xue Gang Goes Against the Tang Dynasty, also listed in the repertoire.

c It is unclear whether this story refers to 陳久仁 or 陳九仁.

d Only the last name is provided, as opposed to the full name.
} 
TABLE 6.1 Repertoire of the Hoc Kian troupe (cont.)

Repertoire $\quad$ Default title English translation
as written by
Teresita Chan

\begin{tabular}{|c|c|c|}
\hline 双李莫 & 双李英 & e \\
\hline 棋盤山 & & Mount Qipan \\
\hline 翠雲山 & & Mount Cui Yun \\
\hline 佘漢招親 & 秦漢招親 & Qin Han marries into the Bride's family \\
\hline 王良下山 & & Wang Liang descends from the mountain \\
\hline 陳清姑下山 & 陳靖姑下山 & Chen Jinggu descends from the mountain \\
\hline 王麗華下山 & 訤梨花下山 & Fan Lihua descends from the mountain \\
\hline 陳榮挂帥 & & Chen Rong assumes command \\
\hline 儀竹山捉虎 & & Hunting for the tiger at Mount Yizhu \\
\hline 蘇后取頭闺 f & 蘇后取頭關 & \\
\hline 借子龍退典禮 & & Using Zilong to depart the ceremony \\
\hline 杜世光比武 & & Du Shiguang displays his martial skills \\
\hline 岳飛收楊再兴 & & Yue Fei defeats Yang Zaixing \\
\hline 取潼闺 & 取潼關 & Invasion at Gate of Tong \\
\hline 取边闺 & 取邊關 & Invasion at the borders \\
\hline 白鹤闺 & 白鶴關 & At the Gate of Bai He (White Crane) \\
\hline 西龍闺 & 西龍關 & At the Gate of Xilong (Dragon of the West) \\
\hline
\end{tabular}

e This is also a story that requires further verification, as I am unsure whether the name Li Ying refers to the main character.

f I have not been able to identify a story related to Su Hou, so the English translation is not provided here.

Non-standard orthography is common in handwritten scripts and I attempt to accurately represent these original characters (久, 秦, 闺, 边, 莫, 劢, 㦸). If the story title conforms to the standard orthography and/or a story usually known in traditional theatre, the part in the middle column is shaded in grey.

As observed in this repertoire, themes that frequently appear include travelling to the Capital, invasions, and descending from mountains. The phrase "travelling to the Capital" can suggest the emphasis on scholarly pursuit often associated with civil plays (wenxi 文戲), whereas "invasions" and "descends from the Mountain" suggest, respectively, martial plays (wuxi 武戲) and stories related to divine arts. 
To my knowledge, the Kaoka playscripts created by Teresita Chan, the current troupe leader of the Hoc Kian troupe in the Philippines, have not received any academic attention. Teresita Chan saw the need to write these playscripts so that new performers, especially those who started with little or no proficiency in Hokkien, can learn the lines. She mentioned to me that her teachers taught her the lines orally, so there was no text prior to her creation. These playscripts attest to the existence of a particular Sino-soundscape as mentioned earlier, notably in Southeast Asia and beyond (Taiwan and Kinmen in particular). ${ }^{24}$ The Philippines is currently the only location within this Sino-soundscape that has sustained the theatrical form closely associated with Nanyin. ${ }^{25}$ While Nanyin itself is still performed in other sites in this Sino-soundscape, Kaoka has not been able to "withstand" the popularity of Gezai opera, its more modern counterpart from Taiwan, as the latter adopts a musical style distinct from Nanyin. The fondness for Nanyin can be regarded as a marker of Filipino Chinese identity, as I argue in this chapter, which has allowed Kaoka to survive in the Philippines. As Kim Chew Ng noted, "a writer in China or Taiwan is perhaps preordained to write in the Sinitic script. Abroad, especially in a country where Hua people are oppressed and regarded as a minority, a writer's choice of the Sinitic script involves a serious value judgement and has significance in terms of cultural identity ... th[is] decision ... requires an exertion of effort, as the language is something that must be 'acquired"' (Ng 2013: 79). The Kaoka playscripts also represent the consistent effort by practitioners to sustain this tradition, even if many do not have the proficiency to write Chinese characters. For the Hoc Kian opera troupe, I have observed that older performers are of Chinese descent, that is, one of their parents or both are Chinese, whereas the younger performers are Filipinos with no Chinese descent. Some of the older performers communicated with me in Mandarin, while Teresita Chan, the troupe leader, communicated in Hokkien and some English. The Kaoka playscripts (Fig. 6.3) are essential learning materials for the performers,

24 Quite similar to the Philippines, Gaojia opera (Kaoka) was the more dominant theatrical form in Kinmen, compared to Gezai opera. The most recent record of a local Gaojia opera troupe was in 2000, but more research is required to understand the situation in Kinmen. For a contextual understanding, see Chia (2019: 76-79).

25 Stenberg (2020: 71-72) also notes that Nanyin (also known as Nanguan) musicians in the Philippines were pivotal in sustaining a related theatrical form in Taiwan, known as nanguan $x i$ 南管戲. 


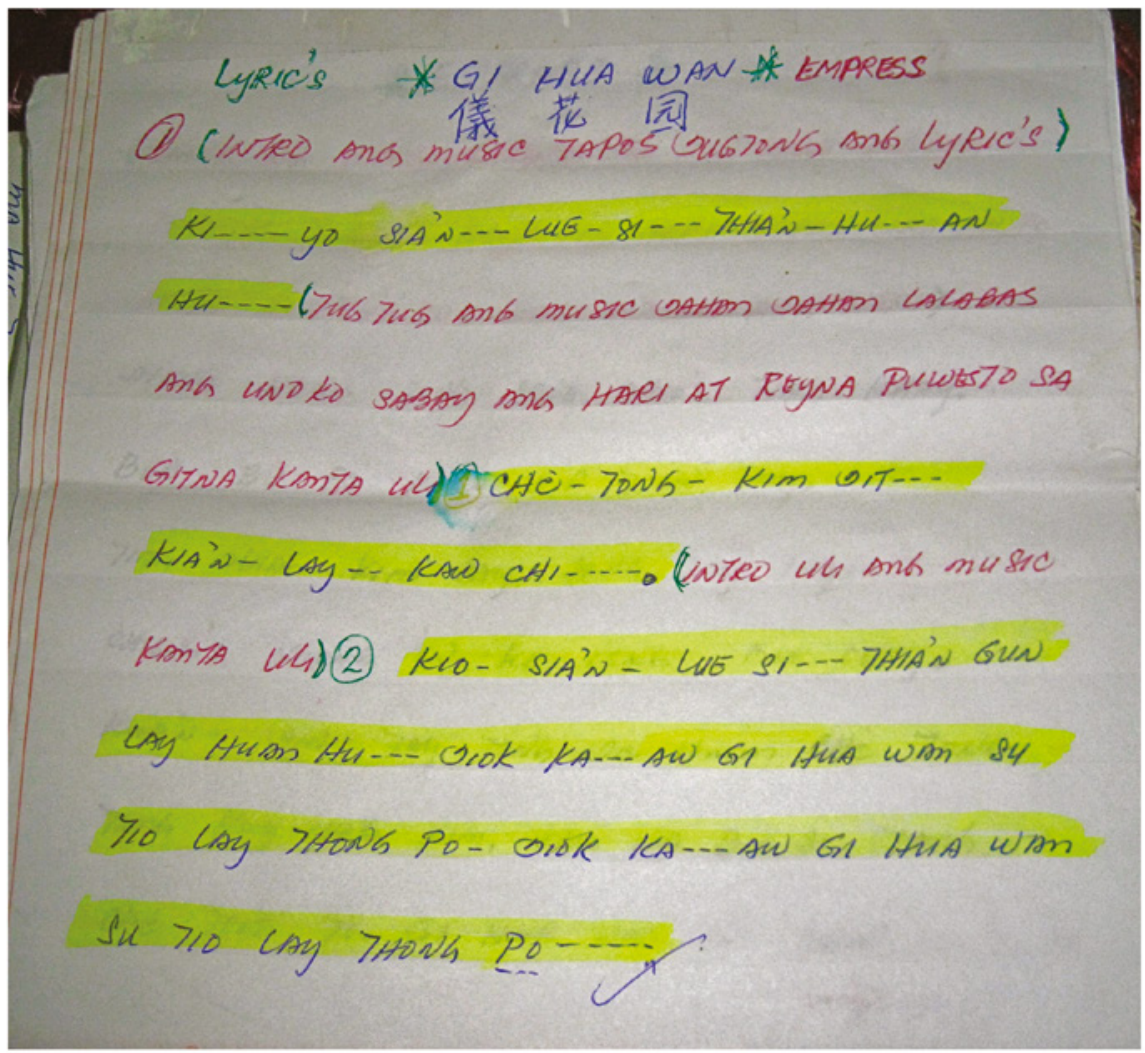

FIGURE 6.3 An image of a Kaoka playscript by the Hoc Kian troupe, photo taken by author with permission of the troupe OWN WORK

especially the younger generation who often start out without any proficiency in Hokkien.

Taking a closer look at the playscripts, they are written in a style quite different from the aforementioned studies on colloquial Hokkien varieties in the Philippines. Compared to studies on the more contemporary version of Hokkien, the Kaoka texts reflect less everyday usage and more theatrical language, in which the performers were specialized. In analysing the selected playscripts, I have also discovered the occurrence of stock phrases commonly used among Hokkien performers outside the Philippines, which will be further discussed below.

Studying these Kaoka playscripts has been challenging, as there are a number of linguistic skills required to provide an informed analysis. First, not being 
a native from the Philippines meant that I was unaware of how Tagalog has influenced the romanized Hokkien script in use. To overcome this lack of proficiency, I consulted with Filipino native speakers who were not ethnically Chinese or Chinese-descended, which meant that they did not speak Hokkien (Ban-lam-ue). They provided some insight about the explanatory notes written in Tagalog, noting that some of the words were misspelt, possibly due to the limited literacy of the scribe or the fact that the script was an earlier form of Tagalog - although the precise time period of the script is unclear - that is less common today. ${ }^{26}$ Secondly, knowing Hokkien is useful to analyse the texts, but this is particularly the case when researching colloquial Philippine Hokkien varieties. The Kaoka playscripts additionally require knowledge of the theatrical language, particularly the one used in Hokkien theatre, in which I have acquired proficiency given my background in this field. To help me with this chapter's preliminary analysis, I have also consulted with different people proficient in both Hokkien and Tagalog, and used various Quanzhou, Zhangzhou and Taiwanese dictionaries as references. ${ }^{27}$

The theatrical language in romanized Hokkien is an important characteristic of the Kaoka playscripts. Table 6.2 illustrates the corresponding Chinese characters that are pronounced (and romanized) differently in the literary and colloquial styles. This reflects a broader phenomenon in the Hokkien language (see also Ding and Churchman in this volume), which is said to be one of the most complex among the Chinese regional languages in terms of differences in colloquial and literary reading (wenbai yidu 文白異讀). ${ }^{28}$ For the sake of comparison, the rightmost column includes Klöter's record of EMH corresponding to the same Chinese character.

26 I am grateful to Dr. Darlene Machell De Leon Espena from the Singapore Management University (SMU), who helped me with understanding the Tagalog translation in the Kaoka scripts. The topic of observed differences between the Tagalog translation and present-day Tagalog usage, which requires the expertise of Tagalog linguists, falls beyond the scope of this chapter. As the Tagalog sections provide explanatory notes, a general understanding sufficed to help me analyse the source text.

27 The dictionaries used in this analysis include Zhou (2006) and Taiwan Minnanyu Changyongci cidian.

28 Lin (2008: 49-51). Although Lin suggests that the most complex variety - in terms of such differences in literary and colloquial reading - is the Quanzhou vernacular, I think it is hard to measure its complexity. The coexistence of colloquial and literary readings applies to the Zhangzhou and Taiwanese vernaculars as well, although I will limit the discussion to the Kaoka playscripts. 
TABLE 6.2 Literary Hokkien in Kaoka playscripts

\begin{tabular}{|c|c|c|c|c|}
\hline $\begin{array}{l}\text { Literary Hokkien of } \\
\text { Kaoka playscripts }\end{array}$ & $\begin{array}{l}\text { Corresponding } \\
\text { Chinese } \\
\text { characters }\end{array}$ & $\begin{array}{l}\text { Colloquial } \\
\text { Hokkien }\end{array}$ & $\begin{array}{l}\text { Early Manila } \\
\text { Hokkien } \\
\text { (Klöter 2011) }\end{array}$ & $\begin{array}{l}\text { English } \\
\text { gloss }\end{array}$ \\
\hline bio & 母 & $b u$ & & mother \\
\hline chian & 前 & tsing & chēng, cing 5 & front \\
\hline $\operatorname{din}(\operatorname{lin})$ & 人 & lang & $\begin{array}{l}\text { lang, } \text { lang }^{5}, \\
\text { lāng }^{\mathrm{a}}\end{array}$ & person \\
\hline ha & 下 & $e$ & $\check{e}, e e^{3}$ & to descend \\
\hline hak & 學 & $o h$ & & learn \\
\hline hua & 花 & hue & hua, hue & flower \\
\hline hun & 分 & pun & hún, hun ${ }^{1}$ & separate \\
\hline ngo & 我 & gua & $g o a, g u a^{\mathbf{b}}$ & I \\
\hline san & 山 & suann, sua & $\operatorname{san}^{1}$, suă & mountain \\
\hline$t i$ & 知 & tsai, zai & chai & to know \\
\hline to & 到 & kau & $c \hat{a} u, k a u^{7}$ & to reach \\
\hline
\end{tabular}

a Recorded by Gonzales (2018: 33) as láng and by Yap (1980: 110, 132) as lang, láng, and láy.

b Gonzales (2018: 34) records it as guâ.

Performers of traditional Hokkien theatre use a mix of literary and colloquial registers. For example, characters involving learned men, officials, and the royal court speak and sing more in the literary style, whereas those of a lower status, such as the commoners, use a more colloquial form. Performers tend to acquire or learn phrases in literary style as stock phrases, so that they can be applied whenever the need arises. Some examples of these stock phrases in the literary style also exist in the Kaoka playscripts, as listed in Table 6.3:

TABLE 6.3 Stock phrases of literary Hokkien observed in the Kaoka playscripts

\begin{tabular}{lll}
\hline Stock phrases & Kaoka playscripts & Corresponding English meaning \\
\hline 免禮 & bian le & dispense with ceremony \\
且慢 & chia ban & please wait \\
妾身 & chiap $\sin ^{\mathrm{a}}$ & wife (referring to oneself)
\end{tabular}

a The character 身 'body' is recorded by Klöter $(2011: 326,327)$ as sin and syn. 
TABLE 6.3 Stock phrases of literary Hokkien observed in the Kaoka playscripts (cont.)

\begin{tabular}{lll} 
Stock phrases & Kaoka playscripts & Corresponding English meaning \\
\hline 膝下無嗣 & han ha bu si & no progeny \\
奉萬歲聖旨 & hong ban sue sing chi & following orders of the Emperor \\
飲酒作樂 & im chiw chok lok & drink and make merry \\
共守共結髮 & kang siw kang kiat huat & to stay together in marriage \\
(夫妻) 結髮 & kiat huat & marriage of husband and wife \\
叫聲老爺 & kio sia'n lawya & I call to you, my lord \\
保庇我夫早轉/回來 & po pigua hucha teng & bless my husband for an early \\
& lay & return
\end{tabular}

The stock phrases listed in Table 6.3 are found in the Kaoka playscripts and display similarities with the theatrical language that I have studied elsewhere (Chia 2018: 31, Table 6.3). Such similarities demonstrate that Kaoka performers in the Philippines adhere to the language and performance conventions observed in Hokkien theatre more generally.

There are about 35 to 40 Kaoka playscripts that I was given permission to read and document. As it is not possible to cover all within this chapter, I will provide an overview of the playscripts. A number of the texts include translations into Tagalog and appear to be general lines for performers. The Gi Hua Wan (儀花園 Yi Hua Yuan) 'Righteous Garden', for example, features the Emperor's and Empress' lines in romanized Hokkien and Tagalog (see Fig. 6.3 above). Flipping through these playscripts, a recurring theme is the imperial court. There are also song lyrics related to this theme, beckoning the question why it appeared so frequently. I linked this to my previous study of Gezai opera in Singapore. Unlike some other theatrical forms such as Teochew opera and Cantonese opera, Gezai opera generally does not have a playscript and performers rely on improvisation and learning orally, depending on their level of literacy. Despite its improvisational nature, performers related to me that they tend to learn by rote certain spoken and sung parts that are specific and allude more to the literary style, particularly for roles like the Emperor. This is harder to improvise and so they would learn through written texts, notes, or oral means and remember them by heart (Chia 2018: 28). The need to remember lines in the literary style by rote, including those of the Emperor, could explain why they frequently appear in the Kaoka playscripts.

For the purposes of this chapter, I have selected one playscript for detailed analysis, titled Ong Le Hua Ha Shan (王麗華下山 Wang Lihua xia shan) 'Ong 
Le Hua descends from the mountains'. At first glance, Ong Le Hua does not appear to be a familiar character in the Hokkien repertoire. However, through a repeated analysis of the storyline and with verification from the author Teresita Chan, I could make sense of the story. It is related to the classical character Fan Lihua (校梨花; Hokkien: Huan Le Hua), since there was an episode where she was sent by her teacher Venerable Mother of Mount Li (黎山 聖母 Lishan Shengmu, some sources have 梨山老母～驪山老母 Lishan Laomu) to descend from the mountains. The names of the two main characters are Ong Le Hua and her father Ong Che Sieng 王志賢 - corresponding to Huan Le Hua and Huan Hong 㚞洪 - and the time period is set in the Ming Dynasty (1368-1644 CE) instead of Tang (618-907 CE). Nevertheless, the storyline remains more or less the same, possibly due to modifications in the process of transmission. Ong Le Hua is sent to the mountains at an early age to learn martial arts from the Venerable Mother of Mount Li. The latter decided that it was time she descended from the mountains to save Ong Le Hua's father, Ong Che Sieng, who was captured by foreign invaders. In this story, Venerable Mother of Mount Li's name remains the same and is key to substantiate that the Kaoka playscript is a modified version of the original story of Fan Lihua Descends from the Mountains (樊梨花下山 Fan Lihua xia shan).

To investigate the nature of the Kaoka playscripts, I first observed whether the scribe has a personal style of writing the romanized Hokkien and whether the same word is romanized consistently. From my initial observation, I noticed that words ending in $\langle a y\rangle$ correspond to $/ a i /$ in the default Hokkien romanization. Examples include lay (lai 來), tay (tai 帶), thay (thai 待) and kay (kai 該). This can be observed in several other examples, which are listed in Table 6.4 below. In Yap's study of the Hokkien borrowings in Tagalog, such as kintsay (khinchai 芹菜) and petsay (peqchai 白菜), this minor orthographic difference is also attested (Yap 1980: 29-31). It is presumably the result of influence from written Tagalog, in which $\langle$ ay $\rangle$ likewise corresponds to /ai/ (rather than $/ \mathrm{e} /$ ). Along similar lines, $\langle\mathrm{aw}\rangle$ in the Kaoka playscripts corresponds to $/ \mathrm{au} /$ in mainstream Hokkien.

Table 6.5 includes the Kaoka text of Ong Le Hua Descends from the Mountains, along with the default Hokkien romanization in the second column. The purpose of juxtaposing both romanizations is to illustrate that the Kaoka playscript adheres quite closely to a general Hokkien romanization. As mentioned before, the Hokkien romanization provided here is informed by Quanzhou, Xiamen, Zhangzhou, and Taiwanese dictionaries. Where these varieties differ internally, I indicate those differences in footnotes or with a slash (/). I have verified this playscript with Teresita Chan, but there are challenges, as she does not write much Chinese and the script also has a number of versions, including 
TABLE 6.4 Romanizations in the Ong Le Hua playscript

\begin{tabular}{llll}
\hline $\begin{array}{l}\text { Chinese } \\
\text { character }\end{array}$ & $\begin{array}{l}\text { Romanization in Kaoka } \\
\text { playscript Ong Le Hua }\end{array}$ & $\begin{array}{l}\text { Generic Hokkien } \\
\text { romanization }\end{array}$ & English gloss \\
\hline 你 & $d i^{\mathrm{a}}$ & $l i$ & you \\
$了$ & diaw & liau & already \\
交 & $k a w$ & $k a u$ & submit \\
該 & $k a y$ & $k a i$ & should \\
快 & $k u a y$ & $k h u a i$ & to hasten \\
來 & lay & lai & to come \\
乃 & nay & $n a i$ & to be \\
帶 & tay & tai & to bring \\
待 & tay & tai & to wait \\
潮 & tiaw & tiau & tide \\
& & &
\end{tabular}

a This is also recorded by Gonzales (2018) as di (a number of examples cited).

b The character 來 'coming' is recorded by Klöter (2011: 222, 223) as lāy or lai ${ }^{5}$.

TABLE 6.5 Analysis of the Ong Le Hua Ha Shan playscript with Chinese and English translations

$\begin{array}{llll}\text { Kaoka playscript } & \begin{array}{l}\text { Generic Hokkien } \\ \text { romanization }\end{array} & \begin{array}{l}\text { Chinese } \\ \text { translation }\end{array} & \text { English translation }\end{array}$

Ngo nayle san sieng Ngo naile san sing bio biona in ongle hua na in ongle hua

\begin{tabular}{|c|c|}
\hline Igun si to hun chiw' & I gun si to hun tshiu \\
\hline gun kay thio ha san & gun kai tioh ha san \\
\hline $\begin{array}{l}\text { tay tha'n to siang san, } \\
\text { chian lay hak ge }\end{array}$ & $\begin{array}{l}\text { tai thann to siang } \\
\text { san tsian lai hakge }\end{array}$ \\
\hline che tay chia'n ba chit & tse tai tshiann pa \\
\hline pin it si sim hiat lay & tsit pinn tsit si sim \\
\hline tiaw & hiat lai tiau \\
\hline
\end{tabular}

\section{那因王麗華 \\ 我乃黎山聖母 I am Venerable \\ Mother of Mount Li. \\ Because for Ong Le \\ Hua,}
伊阮是到分手 She and we have to
(的時候)
go separate ways
阮該著下山
We have to descend from the mountains

帶她到雙山前

來學藝

(Recalling the old times) Bringing her to the Shuang mountains to learn the art 坐待且罷這邊一 as I cannot sit there 時心血來潮 and wait. On my end, it was a decision made with impulse 
TABLE 6.5 Analysis of the Ong Le Hua Ha Shan playscript with Chinese and English (cont.)

\begin{tabular}{|c|c|c|c|}
\hline pt & $\begin{array}{l}\text { Generic Hokkien } \\
\text { romanization }\end{array}$ & $\begin{array}{l}\text { Chinese } \\
\text { translation }\end{array}$ & English \\
\hline $\begin{array}{l}\text { kay thio kut chuy'ni } \\
\text { suan pian ti } \\
\text { haw se se diaw ... ay } \\
\text { ya chia'n ban } \\
\text { na in ong che sieng }\end{array}$ & $\begin{array}{l}\text { kai tioh kut tshui it } \\
\text { suan pian ti } \\
\text { xau } / \text { ho sei si liau ... } \\
\text { ai ia tshia ban } \\
\text { na in ong tse/tsi } \\
\text { tsheng }\end{array}$ & $\begin{array}{l}\text { 該著骨推（掐 } \\
\text { 指）一算便知 } \\
\text { 好是c是了 哎呀 } \\
\text { 且慢 } \\
\text { 那因王志成 }\end{array}$ & $\begin{array}{l}\text { By pinching my fin- } \\
\text { gers, I can predict } \\
\text { This is it. Alas, wait a } \\
\text { moment } \\
\text { Because Ong Che } \\
\text { Sieng (Wang Zhi } \\
\text { Cheng) }\end{array}$ \\
\hline $\begin{array}{l}\text { pi huan ban tiong } \\
\text { diaw it siong }\end{array}$ & $\begin{array}{l}\text { pi huan }{ }^{\mathrm{d}} \text { ban tiong } \\
\text { liau it siong }\end{array}$ & 被番蠻中了一傷 & $\begin{array}{l}\text { ed by the } \\
\text { invaders }\end{array}$ \\
\hline $\begin{array}{l}\text { gua kay thio dieng } \\
\text { to te }\end{array}$ & $\begin{array}{l}\text { gua kai tsu/teo ting } \\
\text { to te }\end{array}$ & $\begin{array}{l}\text { 我該著/得叮 } \\
\text { (囑) 徒弟 }\end{array}$ & to instruct my \\
\hline & & $\begin{array}{l}\text { 下山過（去） } \\
\text { 救你 }\end{array}$ & $\begin{array}{l}\text { lescend from the } \\
\text { untains and save }\end{array}$ \\
\hline lay & $\begin{array}{l}\text { lai bin to te ko/kua/ } \\
\text { ke lai }\end{array}$ & 內面徒弟過来 & $\begin{array}{l}\text { e inside, my } \\
\text { iple }\end{array}$ \\
\hline $\begin{array}{l}\text { put iong-o-to te } \\
\text { lay }^{\mathrm{e}}\end{array}$ & put iong to te lai & 不用 徒弟来 & $\begin{array}{l}\text { Don't have to (stand } \\
\text { on ceremony), come } \\
\text { on in, my disciple }\end{array}$ \\
\hline $\begin{array}{l}\text { na si di thia'n pi huan } \\
\text { ban tiong diaw it } \\
\text { siong }\end{array}$ & $\begin{array}{l}\text { na si li tia pi huan } \\
\text { ban tiong liau it siong }\end{array}$ & $\begin{array}{l}\text { 那是你爹被番蠻 } \\
\text { 中了一傷 }\end{array}$ & $\begin{array}{l}\text { Your father has been } \\
\text { injured by foreign } \\
\text { invaders }\end{array}$ \\
\hline
\end{tabular}

a I and it 'one' are used here, which correspond to the Quanzhou and Zhangzhou romanization. See Zhou (2006: 1071). The word $i$ here should not be confused with 伊 's/he', exemplifying once again the challenges of attempting to analyse Sinophone texts that lack characters, as the same romanization can refer to different corresponding Chinese characters.

b As indicated in Zhou (2006), xau can be written and pronounced as hau.

c This is partly based on script with Chinese characters provided by Teresita Chan. The character 好 'good' is recorded by Klöter (2011) as ho in general (many examples cited throughout the book).

d I could not locate the romanization for 番 in Zhou (2006). It is recorded by Yap (1980: 132) as huân.

e In the Kaoka script, -o- possibly indicates a pause. 
TABLE 6.5 Analysis of the Ong Le Hua Ha Shan playscript with Chinese and English (cont.)

\begin{tabular}{|c|c|c|c|}
\hline Kaol & $\begin{array}{l}\text { Generic Hokkien } \\
\text { romanization }\end{array}$ & $\begin{array}{l}\text { Chinese } \\
\text { translation }\end{array}$ & $n$ \\
\hline $\begin{array}{l}\text { to te lay, gua dieng di } \\
\text { ha san kue kiw }\end{array}$ & $\begin{array}{l}\text { to te lai, gua ting li ha } \\
\text { san kue (khi) kiu }\end{array}$ & $\begin{array}{l}\text { 徒弟來, 我叮你 } \\
\text { 下山過 (去) 救 }\end{array}$ & $\begin{array}{l}\text { Come my disciple, } \\
\text { I instruct you to } \\
\text { descend from the } \\
\text { mountains and do } \\
\text { the rescue }\end{array}$ \\
\hline $\begin{array}{l}\text { di thia'n din chit ke } \\
\text { hue tit tuan uan }\end{array}$ & $\begin{array}{l}\text { li tia lin tsit ke hue tit } \\
\text { thuan uan }\end{array}$ & $\begin{array}{l}\text { 你爹恁 (你们) } \\
\text { 一家回得/去 } \\
\text { 團圓 }\end{array}$ & $\begin{array}{l}\text { Then you and your } \\
\text { father can return } \\
\text { home and reunite }\end{array}$ \\
\hline $\begin{array}{l}\text { to te la tia gua } \\
\text { kaw tay }^{\mathrm{f}}\end{array}$ & $\begin{array}{l}\text { to te lai thiann gua } \\
\text { kau tai }\end{array}$ & 徒弟來聽我交代 & $\begin{array}{l}\text { Listen to my instruc- } \\
\text { tions, my disciple }\end{array}$ \\
\hline $\begin{array}{l}\text { to te lay, tia gua } \\
\text { chua thieng dieng }\end{array}$ & $\begin{array}{l}\text { to te lai, thiann gua } \\
\text { tshua thing ting }\end{array}$ & $\begin{array}{l}\text { 徒弟來, 聽我 } \\
\text { (的話) 帶 } \\
\text { (這國) 廳燈 }\end{array}$ & $\begin{array}{l}\text { Come my dis- } \\
\text { ciple, bring this hall } \\
\text { lantern }\end{array}$ \\
\hline $\begin{array}{l}\text { sok sok ha santi } \\
\text {-o-o-kuayke }\end{array}$ & $\begin{array}{l}\text { sok sok ha san tit } \\
\text { khuaike }\end{array}$ & 速速下山得快計 & $\begin{array}{l}\text { The brief plan is } \\
\text { to quickly descend } \\
\text { from the mountains. }\end{array}$ \\
\hline ho diaw to te khi sin & hau liau to te khi sin & 好了徒弟起身 & $\begin{array}{l}\text { Alright, it is time } \\
\text { to get moving, my } \\
\text { disciple }\end{array}$ \\
\hline $\begin{array}{l}\text { gua kay thio tan thay } \\
\text { siaw sit pa ... diaw }\end{array}$ & $\begin{array}{l}\text { gua kai tioh tan thai } \\
\text { siau sit pa liau }\end{array}$ & $\begin{array}{l}\text { 我該著等待消 } \\
\text { 息罷了 }\end{array}$ & $\begin{array}{l}\text { I will wait here for } \\
\text { your news }\end{array}$ \\
\hline
\end{tabular}

f $L a$ possibly means lay with the omission of $\langle\mathrm{y}\rangle$.

g The character 燈 'lantern, lamp' is recorded by Yap (1980: 132) as tiêy.

There are still minor parts (bold-italicized) that are unclear to me and any error is my own.

the one she remembers and one copied by her student and current Kaoka performer Raquel Espena. I have used the latter playscript because Teresita indicated that she currently does not have the physical copy of the former and the photographs she provided were too blurry to decipher. Although versions differ, the essential content - particularly the role of Venerable Mother of Mount Li, the way she predicted that Ong Le Hua's father would be trapped by foreign invaders, and her advice to Ong Le Hua to descend from the mountains to save her father - has helped me to decipher the text. However, it should be noted that without the context it is difficult to determine the meaning and corresponding Chinese characters, especially when the romanized script has 
no tonal indication, such that one romanized word can correspond to many characters of the same pronunciation.

\section{$5 \quad$ Concluding Remarks}

This study of Kaoka, a traditional theatrical form originating from south Fujian and still performed in the Philippines today, illustrates the diversity and complexity of the Sinophone. Its two prisms of analysis - cultural and linguistic - are deeply intertwined. The timeline I have attempted to reconstruct of the development of Kaoka in the Philippines highlights the prevalence of Nanyin as the bedrock of the interconnected Sino-soundscape that developed among the various Hokkien communities in Southeast Asia and beyond, including Taiwan and Kinmen. It was Nanyin, as I have attempted to demonstrate, that was crucial to sustain the popularity, growth, and continued existence of Kaoka in the Philippines, as the latter has disappeared from other parts of Southeast Asia. The various features of the Kaoka playscripts discussed in the second part, including the colloquial and literary readings, illuminate the linguistic implications of this story. The colloquial-literary dichotomy is less observed in previous studies on Philippine Hokkien, partly because the literary forms are less frequent in everyday usage. However, as I have shown, it is nevertheless important to obtain a more textured sociohistorical picture in order to understand Kaoka and Hokkien theatre in general. In the Philippine context, language and performance have clearly reinvigorated each other. This analysis has furthermore illustrated the preservation and continued use of stock phrases commonly seen in Hokkien theatre elsewhere. The romanization of the Kaoka playscripts closely resembles the romanization of Hokkien in Quanzhou, Zhangzhou and Taiwan, conveying a sense that the creator of these scripts has attempted to adhere as closely as possible to the conventions of Hokkien theatre. In doing so, a unique fragment of the Sinophone lost elsewhere has been preserved in the Philippines.

\section{References}

Bai, Yonghua 白勇華, 'Zhanzhuan Dongnanya: Gaojiaxi haiwai bainian 輾轉東南亞: 高 甲戲海外百年 (1840-1940)', Fujian luntan, renwen shehui kexue ban, 8 (2011): 64-68. Chan Yap, Gloria, Hokkien Chinese borrowings in Tagalog (Pacific Linguistics, Series B, 71, Canberra: Australian National University, 1980).

Chen, Zhiping 陳支平 and Xu Hong 徐泓, Minnan wenhua baike quanshu 閩南文化百 科全書 (Fuzhou: Fujian renmin chubanshe, 2009). 
Chia, Caroline, 'Gezai xi in Singapore: Oral transmission, improvisation and dependence on "Fixed Texts"', CHINOPERL, 37/1 (2018): 1-41.

Chia, Caroline, Hokkien theatre across the seas (Singapore: Springer Singapore, 2019).

“Fei hua xiqu de xingqi 菲華戲曲的興起 (-1945)”, in Zhou Ning (ed.), Dongnanya huayu xijushi (xiace) 東南亞華語戲劇史 (下冊), vol. 2 (Xiamen: Xiamen daxue chubanshe, 2007), 802-71.

"Fujian sheng difangzhi bianji weiyuanhui" (ed.), Fujian sheng zhi, xiqu zhi 福建省志 戲曲志 (Beijing: Fangzhi chubanshe, 200o).

Gonzales, Wilkinson Daniel Ong Wong Gonzales, 'Philippine Hybrid Hokkien as a Postcolonial Mixed Language: Evidence from Nominal Derivational Affixation Mixing' (MA thesis, National University of Singapore, 2018).

Goody, Jack, Literacy in Traditional Societies (Cambridge: Cambridge University Press, 1975).

Hung, Wei-jen 洪惟仁, 'Shiliu shiqi shiji zhijian Lüsong de Zhangzhou fangyan 十六、 七世紀之間呂宋的漳州方言', Lishi dili 歷史地理, 30 (2014): 215-38.

Klöter, Henning, The Language of the Sangleys: A Chinese vernacular in missionary sources of the seventeenth Century (Leiden; Boston: Brill, 2011).

Lin, Huadong 林華東, Quanzhou fangyan yanjiu 泉州方言研究 (Xiamen: Xiamen daxue chuban she, 2008).

Ministry of Education, Taiwan Minnanyu Changyongci cidian. https://twblg.dict.edu. tw/holodict_new/default.jsp.

Ng, Kim Chew, 'Sinophone/Chinese: "The South where Language is lost" and Reinvented, translated by Brian Bernards', in Shu-mei Shih, Chien-hsin Tsai and Brian Bernards (eds.) Sinophone Studies: A Critical Reader (New York: Columbia University Press, 2013), 74-92.

Ng, Percy, 'Kao Ka, the Chinese Opera in the Philippines: A preliminary socio-historical study' (MA thesis, University of the Philippines Diliman, 2016).

Pan, Rongyang 潘榮陽, ‘Gaojiaxi yu Min-Tai shehui bianqian 高甲戲與閩台社會變遷’, Dongnan Xueshu 東南學術, 3 (2013): 219-25.

Ruizendaal, Robin, Marionette theatre in Quanzhou (Boston: Brill, 20o6).

Shih, Jui-lou 施瑞樓, 'Lukang Juying she Nanguanxi zhi yanchu ji “Yichun liu shan” shenfen zhi tan tao 鹿港聚英社南管戲之演出及〈益春留傘〉身段之探討 (MA thesis, National Taiwan Normal University, 2012).

Shih Shu-mei, 'Introduction: What Is Sinophone Studies?', in Shih Shu-mei, ChienHsin Tsai and Brian Bernards (eds.), Sinophone Studies: A Critical Reader (New York: Columbia University Press, 2013), 1-16.

Stenberg, Josh, 'Xiqu in the Philippines: From Church Suppressions to MegaMall Shows', Journal of Chinese Overseas, 16 (2020): $5^{8-89}$. 
Tan, Sooi Beng and Nancy Yunhwa Rao, 'Introduction - emergent Sino-soundscapes: musical pasts, transnationalism and multiple identities', Ethnomusicology Forum, 25/1 (2016): 4-13.

Wickberg, Edgar, 'Hokkien-Philippines familial transnationalism, 1949-1975', in Maria N. Ng and Philip Holden (eds.), Reading Chinese transnationalisms (Hong Kong: Hong Kong University Press, 2006).

Wu, Shaojing 吳少靜, 'Minnan yinyue zai Dongnanya de chuanbo 閩南音樂在東南亞 的傳播, Overseas Chinese Journal of Bagui, 4 (2006): 24-28.

$\mathrm{Yu}$, Anson, 'Fading glory: Chinese opera in the Philippines', Tulay Fortnightly (17 April 2007): 8-11.

Yu, Anson, 'Kaoka: A dying art', Tulay Fortnightly (October 22 to November 2013): 8-10.

Zhou, Changji 周長楫 (eds.), Minnan fangyan da cidian 閩南方言大詞典 (Fuzhou: Fujian renmin chubanshe, 2006).

Zhuang, Changjiang 莊長江, Quannan Xi Shi Gou Chen 泉南戲史鉤沉 (Taipei: Guojia chubanshe, 2008).

Zhuang, Changjiang 莊長江, Quanzhou xiban 泉州戲班 (Fuzhou: Fujian renmin chuban she, 2006).

Zhuang, Guotu 莊國土, Feilübin huaren tongshi 菲律賓華人通史 (Xiamen: Xiamen daxue chubanshe, 2012). 